Review

\title{
Chemicals and Allied Products Waste Treatment
}

\author{
Yung-Tse Hung ${ }^{1}$, Erick Butler ${ }^{1, *}$ and Ruth Yu-Li Yeh ${ }^{2}$ \\ 1 Department of Civil and Environmental Engineering, Cleveland State University, Cleveland, \\ OH 44115, USA; E-Mail: yungtsehung@yahoo.com
}

2 Department of Chemical Engineering, Minghsin University of Science and Technology, Hsin-Chu, 304 Taiwan; E-Mail: yehyl@must.edu.tw

* Author to whom correspondence should be addressed; E-Mail: erick.ben.butler@gmail.com; Tel.: +216-687-2401; Fax: +216-687-5395.

Received: 1 May 2011; in revised form: 26 May 2011 / Accepted: 26 May 2011 /

Published: 14 June 2011

\begin{abstract}
A review of the literature published from 2008 to 2010 on topics related to chemicals and allied products is presented. The review considered several sections such as waste management, physicochemical treatment, aerobic treatment, anaerobic treatment, air emissions, soils and groundwater, and reuse.
\end{abstract}

Keywords: chemical waste; waste treatment; waste management; remediation

\section{Introduction}

Entering into the 21st century, science and engineering has made great strides in its technological advances for the treatment and handling of wastes related to chemicals and allied products. Having an origin that began with attempting to comply with federal regulations, the types of mechanisms that have been purposed to handle various wastes has changed due to increasing knowledge within the field. This can be attributed to the interdisciplinary collaboration between various science and engineering fields. While conventional waste handling techniques such as landfilling and conventional wastewater treatment are still in use, the emphasis has changed to reduce the amount of product following treatment and somehow generate a product from waste collected. This has led to the popularity of many techniques such as ozonation, ultraviolet irradiation, and other chemical treatment 
methods. With the use of these new technologies, one is capable of treating wastes that have not been treated before due to the possible problems associated with using traditional methods. Having a plethora of opportunities to explore new technologies, it is therefore important to make a concerted effort to consider what has occurred within waste handling and treatment. The purpose of this text is to provide a study of waste handling methods that cover topics from 2008 to 2010 concerning waste management, physicochemical treatment, aerobic and anaerobic treatment, air emissions, soils and groundwater, and reuse for wastes related to chemicals and allied products.

\section{Waste Management}

Devi et al. discussed a novel method of treating zirconium radioactive waste by using ion-exchange resins for separation of cobalt and antimony from zirconium occurred, where the decontamination factor was greater than $10^{3}$, achieved in an ion-exchange range with cobalt and antimony, reducing the waste volume [1]. Ko et al. found that conventional animal feeding operations (CAFOs) consider 424 microbial air samples and 12 CAFOs analyzed using indicator and pathogenic microorganisms, where $4.5 \%$ fecal coliform, 1.2\% E.coli, 22.2\% Clostridium, and $12.3 \%$ total coliphage. However, when alternative waste treatment technologies were applied, these technologies assisted in maintaining these microorganisms during on-farm treatment and management processes [2].

Cobo et al. compared 2-propanol and molecular $\mathrm{H}_{2} / \mathrm{MeOH}$ as reducing agents for hydrodechlorination of dioxides with a $2 \%$ wt of $\mathrm{Pd} /$ gamme- $\mathrm{Al}_{2} \mathrm{O} 3$ and concluded that complete dioxin degradation occurred when 2-propanol was a reducing agent and solvent, as compared with using $\mathrm{H}_{2} / \mathrm{MeOH}$ which diminished the efficiency [3]. Schiffman et al. considered odor emissions from swine facilities modeling at a distance from 200 and $400 \mathrm{~m}$ downwind using an Eulerian-Lagrangian model. The results found that odor did not extend beyond a $400 \mathrm{~m}$, as long as the air was not turbent within the day, while at night, cooling where stable boundary layer by long wave radiation, also swine housing was based on odor along with sources as compared to waste management types [4].

Muhle et al. compared municipal solid waste in Germany and the United Kingdom for overall emissions, where it was determined that Germany relied more on recycling and recovery as compared to the United Kingdom. The values reflected $\mathrm{CO}_{2}$ emissions of $175 \mathrm{~kg} \mathrm{CO}_{2}$ equivalents/t in Germany, versus $34 \mathrm{~kg} \mathrm{CO}_{2}$ equivalents/t in the United Kingdom [5]. Roudil et al. considered a natural uranium oxide sample from Pet At Ran in Vendee region of France for the purpose of considering changes in $\mathrm{UO}_{2}$ and $\left(\mathrm{U}, \mathrm{PuO}_{2}\right)$ matrixes with nuclear waste management. Helium (He) diffusion coefficients showed that 5\% maximum during $320 \mathrm{Ma}$ was concerned; 33\% residual that in matrix and vacancy and defects; $66 \%$ bubbles were found by HRTEM [6].

Davoli et al. conducted an integrated risk assessment study within $5 \mathrm{~km}$ from a landfill accepting non-hazardous waste, where factors such as emissions, maximum chronic population exposure. The overall effects look at carcinogenic compounds and diffusive emissions and noticed that cancer and non-cancer risks were lower than international agencies emissions such as World Health Organization and the United States Environmental Protection Agency [7].

Othman et al. considered compiling research on the presence of plastics and additional components that are within electronics that have the potential of being used within raw material and energy 
recovery. It was discovered by using the Dulong formula that electronic waste has a calorific value of $30,872.42 \mathrm{~kJ} / \mathrm{kg}$, a value lower emissions for the Environment Quality Act of 1974 [8].

Zhang et al. concluded that considering the use of organiochlorine pesticide contamination and found that pesticides are present within those soils. In addition, the authors suggested that human population within the vicinity of the soils were under a threat to being exposed to those pollutions, as it requires treatment technologies to rid those pesticides from the soils [9]. Zhang et al. found that considering heavy metal contamination in municipal solid waste (MSW) in China, where $\mathrm{Zn}, \mathrm{Cr}, \mathrm{Cu}$, and $\mathrm{Pb}$ is greater than $100 \mathrm{mg} / \mathrm{kg}$, while $\mathrm{Ni}, \mathrm{Cd}$, and $\mathrm{Hg}$ followed. Because putrescible waste and indistinguishable particles (PU), plastics were the materials in the MSW, the authors considered a MSW management system using physicochemical fractionation [10].

Asrupt et al. concluded that receiving plastic waste in various forms such as clean, mixed/contaminated waste, and plastic waste as fuel at a material recover facility. The facility was able to save money on recycling the plastic, specifically in carbon dioxide emissions from electricity production; however, it was not responsive to global warming [11].

\section{Physicochemical Treatment}

Sorption. Homem et al. found that the optimum conditions for amoxicillin sorption is capable of completion when the initial concentration is $450 \mathrm{mu} \mathrm{g} / \mathrm{L}, 50 \mathrm{mg} / \mathrm{L}$ adsorbent, temperature of $303 \mathrm{~K}$, and dp $600 \mathrm{mu}$ m. Pseudo second-order kinetics determined to be the best, as Langmuir was the best isotherm [12].

Bhatnagar et al. found that the maximum sorption capacity of nano-alumina for nitrate removal was $4.0 \mathrm{mg} / \mathrm{g}, 25{ }^{\circ} \mathrm{C}$ temperature, and a $\mathrm{pH}$ of 4.4 . The nitrate sorption was expressed by means of a Langmuir isotherm model [13].

Wang et al. found that using a PS-EDTA resin for adsorbing $\mathrm{Cu}(\mathrm{II})$ and $\mathrm{Pb}(\mathrm{II})$ and found that a $\mathrm{pH}$ of 6, adsorption capacity removal efficiencies were $99.8 \%$ for $\mathrm{Cu}$ (II) and $99.6 \%$ for $\mathrm{Pb}$ (II, The kinetics were pseudo-second order model, where the column capacity for the two heavy metals were a bed height of $0.15 \mathrm{~m}$, hydraulic loading rate of $2.5 \mathrm{~m}^{3} / \mathrm{hm}^{2}$, and feed concentrations of 50 and $100 \mathrm{mg} / \mathrm{L}$ [14].

Chen et al. stated that perfluorooctane sulfonate was sorbed by oil and oil-derived black carbon as there was a relationship with $\mathrm{pH}$ and also $\mathrm{Ca}^{+2}$. In addition, the authors stated that environmental conditions and aqueous concentrations also were major influences when it came to black carbon within perfluroroctane sulfonate [15]. Mori et al. concluded that using crystal violet cationic dye onto polyether type polyurethane foam determined that the isotherms were Langmuir and Freundlich isotherms. It was also determined that at the optimum conditions would provide a removal efficiency of around $92 \%[16]$.

$\mathrm{Li}$ et al. concluded that removing 4-chlorophenol was capable by means of using beta-cyclodextrin polmer as it was noticed that high sorption capacity was registered when the initial concentration did not exceed $24.4 \mathrm{mg} / \mathrm{g}$. It was also determined that the adsorption kinetics as a pseudo 2nd order equation [17].

Other Physical Chemical Methods. Zheng et al. found that ultrasound degradation combined with $\mathrm{H}_{2} \mathrm{O}_{2}$ of direct pink using $\mathrm{NaCl}$ and $\mathrm{CuSO}_{4}$ when the $\mathrm{pH}$ was 3.0 , power of $150 \mathrm{~W}, 78 \%$ degradation was achieved using $50 \mathrm{mu} / \mathrm{L} \mathrm{H}_{2} \mathrm{O}_{2}$ and $\mathrm{CuSO}_{4}$, and a treatment time of $120 \mathrm{~min}$ [18]. 
Katuri et al. concluded that using a laccase-membrane reactor for the decolorization of acid black $10 \mathrm{BX}$ by means of white rot fungi Pleurotus ostreatus 1804, where it was determined that optimum treatment occurred at $30^{\circ}$ Celsius, a reaction time of $120 \mathrm{~min}, \mathrm{pH}$ of 6 , and a concentration of $20 \mathrm{mg} / \mathrm{L}$ [19]. Hasal and Penizkova observed how Penicillin G is capable of being hydrolyzed by using a electro-membrane reactor, as it was contingent on the mean residence time, electric current density, and membrane enzyme activity. The authors determined that using electric current application would increased the conversion of Penicillin G by $200 \%$ [20].

Saravanane and Sundararaman discussed the effects of loading rate and hydraulic retention time on the removal of cephalsopsporin and its intermediates by using bioaugmentation. The authors stated that the purpose of this is to determine methods to remove the compounds prior to discharge as it is current against regulatory standards [21]. Mohan et al. found that using treatment with microbial fuel cells for chemical wastewater was contingent on power generation and organic substrate loading rate where optimum conditions were $716 \mathrm{mV}, 2.84 \mathrm{~mA}$, organic loading rate (OLR) of $1.105 \mathrm{~kg} \mathrm{COD} / \mathrm{m}^{3} \mathrm{~d}$ and $731 \mathrm{mV}, 2.97 \mathrm{~mA}$, OLR of $1.404 \mathrm{~kg} \mathrm{COD} / \mathrm{d}$. The maximum power was $0.73 \mathrm{~kW} / \mathrm{kg} \mathrm{COD}_{\mathrm{R}}$ and $0.49 \mathrm{~kg} / \mathrm{COD}_{\mathrm{R}}$, current density of $339.7 \mathrm{~mA} / \mathrm{m}^{2}$, and $335.43 \mathrm{~mA} / \mathrm{m}^{2}$ with a $50 \mathrm{ohm}$ resistance [22].

Beler-Baykal and Allav compared real and simulated fertilizer wastewater samples that removal of ammonium, where surface capacities were at $14 \mathrm{ng}$ Ammonium/g clinoptilolite. The authors found that using natural zeolite clinoptilolite as a treatment towards ammonium and nitrogen control is based on $\mathrm{pH}[23]$.

Oxidation, ozonation. Ruan et al. found that ozone with microelectrolysis was able to oxidize reactive red $\mathrm{X}-3 \mathrm{~B}$ by removing $99 \%$ color, $85 \% \mathrm{COD}, 59 \% \mathrm{TOC}$, and $74 \% \mathrm{AOX}$ as long as the conditions were $1 \mathrm{~g} / \mathrm{L}$ concentration, $\mathrm{pH}$ of 9 , temperature of $60^{\circ}$ Celsius, $400 \mathrm{~g}$ iron scrap with a diameter of 0.9 to $2.0 \mathrm{~mm}$, and $10 \mathrm{~g} / \mathrm{h}$ ozone flow rate [24]. Author Gulnaz concluded that the use of adsorption by Chara vulgaris was capable of removing various dyes within a $\mathrm{pH}$ range between 2 and 4, where adsorption was communicated by using pseudo-second order kinetics [25]. Turhan and Turgut concluded that the use of ozonation treatment for two hours was able to remove dyes within textile wastewater in half, specifically degradation that occurs within $10 \mathrm{~min}$ [26].

Merle et al. concluded that using adsorption and ozone compounds such as 2,4-dichlorophenol and nitrobenzene would be capable of decomposing compounds within the system, where activated carbon had a suitable adsorbent and decomposition of ozone [27]. Wang et al. concluded that by using a biofilter with ozone concluded that the chlorobenzene had the capability to increase by $50 \%$ when the ozone concentration increased to $120 \mathrm{mg} / \mathrm{m}^{3}$ [28].

Garoma et al. found that oxidation of Bisphenol A (BPA) and its intermediation found that it was resistant to ozonation when $\mathrm{BPA}$ was registered at $51 \mathrm{M}$, corresponding of $2.1 \%$ catechol, $1.1 \%$ resorcinol, $0.9 \%$ acetone, and $0.3 \%$ formaldehyde of the initial concentration was present [29]. Gagnon et al. found that ozone could be a powerful disinfectant for pharmaceutical wastewater using UV radiation, and ozone and perfomic acid conducted in a Montreal Wastewater Treatment Plant. Removal of pharmaceutical waste triclosan was as high as $70 \%$, relating to the presence of ozone $(20 \mathrm{mg} / \mathrm{L})$, while UV irritation only removed at 40\% [30]. Di Iaconi et al. concluded that with a combination of a sequencing batch biofilm reactor (SBBR) to determine oxygen uptake rate, total protein content, extracellular polymeric substance, and hydrophobicity. The results determined that an 
ozone dose of $120 \mathrm{mg} / \mathrm{O}_{3}-\mathrm{L}$, sludge production was reduced $25-30$ times reducing $60 \%$ of the costs. However, biomass activity and structure were not affected by ozone [31].

Irridiation, catalysis, metal complexes. Xiao et al. found that total organic carbon (TOC) removal was $95 \%$ by catalytic ozonation of 2,4-dichlorophenol with permanganate $\left[\mathrm{MnO}_{4}\right](0.5 \mathrm{mg} / \mathrm{L})$, provided the $\mathrm{pH}$ is below $8.5 . \mathrm{MnO}_{4}$ assistance in mineralization was affected by conditions, provided that the conditions were acidic, as $\mathrm{MnO}_{4}$ was reduced to $\mathrm{Mn}^{+2}$ for homogenous catalysis [32] Sanchez-Polo et al. considered gamma irritation as a way to decompose and mineralize nitroimidazoles, where it was noticed that by the presence of optimum $\mathrm{H}_{2} \mathrm{O}_{2}$, it is capable of accelerating the degradation of nitroimidazoles within acidic conditions. In addition, it was noticed that gamma irridiation was able to reduce toxicity within the system with increasing doses [33]. Authors Naddeo et al. concluded that by using sonolysis for wastewater remediation of pharmaceutical wastes is contingent on power densities, acidic conditions, and dissolved air presence. In addition, the authors reported a relationship between concentration of pharmaceuticals and also reaction rate, and also concluded that mineralization allows for complete biodegradation of by-products [34]. Wang et al. found that a photocatalytic reactor with a $\mathrm{TiO}_{2}$ catalyst was capable of treating Acid Red 4 , provided that the parameters considered are flow configuration, flow rate, dye concentration, height intensity, and catalyst loadings [35]. Wu and Li found recovery of phenol from 2,500 to 2 ppm using alkyl phenol from simulated wastewater in a horizontal membrane reactor, where ion-exchange capacity, water content, and membrane thickness. They used a quaternary ammonium membrane from polymerizing chloroethyl styrene and dimethylbenzene [36].

Extraction, electrolysis, electrochemical. Zhou et al. found total nitrogen $(51.9 \%), \mathrm{NH}_{4}-\mathrm{N}(70 \%)$ and $\mathrm{NO}_{3}-\mathrm{N} \quad(50.94 \%)$ when treating pharmaceutical wastewater using an iron-carbon micro-electrolysis system, provided that iron/carbon granulation was $0.425 \mathrm{~mm}, \mathrm{pH}$ of 3 , iron-carbon ratio of 3 , gas-water ratio of 5 , and a hydraulic retention time of $1.5 \mathrm{~h}$ [37]. Prieto et al. compared solid-phase extraction and microextraction and concluded that both were capable of capturing pesticides. However, it depends on preference whether to use each type--solid-phase microextration is inexpensive, while solid-phase extraction is more precise [38].

Wang et al. concluded that by using internal micro-electrolysis coagulation, biological treatment, and activate carbon systems were capable of reducing COD up to $96 \%$ through the whole system, as it was determined that the majority of the processes within biological treatment were capable of removing the COD present in the wastewater. The authors concluded that the removal of COD was sufficient to meet Chinese tertiary discharge standards [39]. By using praseodymium, Han et al. used a $\mathrm{SnO}_{2} / \mathrm{Ti}$ electrode for electrocatalysis was undergone through a model. From a model considering the optimum current density, electrolysis time, dope $\mathrm{P}-\mathrm{T}$, and $\left(\mathrm{SnO}_{2} / \mathrm{Ti}\right.$ : $\left.\mathrm{Al}\right)$ ratio, $\mathrm{COD}$ wiping removed 94.6\% COD (392 to $20 \mathrm{mg} / \mathrm{L}$ [40].

Novel process. Liu et al. determined that an integrated biological and electrochemical oxidation (BEO) with a boron-doped diamond electrode treating biorefactory pesticide wastewater with acetemiprid concentration of $1000 \mathrm{mg} / \mathrm{L}$. The results concluded that $\mathrm{BOD}_{5} / \mathrm{TOC}$ ratio was increased to 1.17 a $40 \%$ reduction in toxicity in $3 \mathrm{~h}$, and a removal of acetamiprid and TOC [41]. Yang et al. introduced a combined microwave enhanced Fenton processes, making it possible to treat high concentrated pharmaceutical wastewater, with a 57\% efficiency of COD and increase of the $\mathrm{BOD}_{5} / \mathrm{COD}$ ratio from 0.165 to 0.470 , exhibiting higher treatment efficiency. It was determined that 
microwave power, radiation time, $\mathrm{pH}$, and $\mathrm{H}_{2} \mathrm{O}_{2}$ and $\mathrm{Fe}_{2}\left(\mathrm{SO}_{4}\right)_{3}$ concentrations affected the treatment efficiency [42].

Hybrid proceses. Mozia et al. found that azo dye Acid Red 18 could remove 49-64\% higher for the hybrid photocatalytic membrane reactor with photocatalysis and membrane distillation. The dye that considered a A-799-1 h catalyst developed by a loading of $0.5 \mathrm{~g} / \mathrm{dm}^{3}$. Preparation of catalyst was intensive $-1 \mathrm{~h}$ calcinations with $700{ }^{\circ} \mathrm{C}$ from amorphous $\mathrm{TiO}_{2}$ from the production line at a Chemical Factory Police in Poland [43].

\section{Aerobic Treatment}

Aerobic bio-treatment. Heger et al. considered four aerobic treatment systems to treat milkhouse wastewater on nine dairy farms, concluding that Biochemical Oxygen Demand (BOD) was removed from $539 \mathrm{mg} / \mathrm{L}$ to $173 \mathrm{mg} / \mathrm{L}$, while Oils and Grease (O\&G) reduced from $89 \mathrm{mg} / \mathrm{L}$ to $9 \mathrm{mg} / \mathrm{L}$ when the flow rate range was between 0.63 to $2.31 \mathrm{~m}^{3} / \mathrm{d}$ using primary treatment in septic systems [44]. You and Teng compared an aerobic membrane bioreactor and aerobic membrane by means of $L$. lactis for the removal of Reactive Black 5 and concluded that the dye was successfully mineralized when using the combined system, while both treatment processes met the Taiwan EPA's effluent criteria. The water removed was capable of being used for other resources such as toilet flushing and landscaping [45].

Aerobic activated sludge reactors. Wang et al. experimented using aerobic granules in three sequencing batch reactors (SBR, One SBR was a control, while two had $\mathrm{Cu}$ (II) and $\mathrm{Ni}(\mathrm{II})$ with the heavy metal concentrations increasing to $15 \mathrm{mg} / \mathrm{L}$. The results determined that $\mathrm{Cu}(\mathrm{II})$ was affected by biomass concentration, bioactivity, and biodiversity of the aerobic granules [46].

Using aerobic granular sequencing batch reactor (GSBR) with an inlet concentration of 100 to 2,000 $\mathrm{mg}$ phenol/L, cycle time between 14 and $24 \mathrm{~h}$ and filling cycling time between 1 and $4 \mathrm{~h}$, Mourssavi et al. found that $99 \%$ phenol was removed from saline wastewater when phenol was $1,000 \mathrm{mg} / \mathrm{L}$ with a time of $17 \mathrm{~h}$ for cycle, while TDS was reported as $8 \%$ [47].

Authors Esteve et al. studied the use of an activated sludge aerobic treatment for the purpose of degrading thirteen pesticides, noticing that biological treatment can treat $97 \%$ of twelve of the thirteen pesticides. In addition, the authors noted that flocculation (sedimentation) must be added to maintain the biomass floc that had been destroyed by the pesticides [48].

Effects on treatment performance. Hussain et al. explored recent studies have concluded that pesticides have negative connotation for both plants and nitrogen fixing rhizobacteria, having an overall affect on the processes of biological nitrogen fixation, including addition processes such as nitrification, denitrification, ammonification, redox reactions, and methanogenesis [49].

Christian et al. used a high rate activated sludge reactor (HRAS) with a high sheer venturi reactor removed $81-92 \%$. This value is varied based on the organic loading, where it ranged between 3 and $85 \mathrm{~kg} \mathrm{COD} / \mathrm{m}^{3} \mathrm{~d}$, where the solid retention time (SRT) is less than two hours and two days [50].

Nutrient Treatment. Yuan et al. concluded that the nitrification rate was reduced from $0.0595 \mathrm{mg}$ $\mathrm{NH}_{4} / \mathrm{N}$ g MLVSS to $0.0251 \mathrm{mg} \mathrm{NH} / \mathrm{N}$ g MLVSS and dissolved oxygen concentrations from 4.5 to $1.0 \mathrm{mg} / \mathrm{L}$ within a sequencing batch reactor studying parameters such as dissolved oxygen, ORP, and $\mathrm{pH}$. Overall, nitrification was able to be improved by high DO, while removing total inorganic nitrogen (TIN) [51]. 
Zeng et al. used a continuous anaerobic-anoxic-aerobic (A2O) process treating domestic wastewater where the nitrate accumulation rate was $90 \%$, ammonia removal efficiency at $95 \%$, where nitrification-denitrification occurred at both dissolved oxygen levels from 0.3 to $0.5 \mathrm{mg} / \mathrm{L}$ and 1.5 to $2.5 \mathrm{mg} / \mathrm{L}$ [52]. Guo et al. found that nitrogen removal with nitrate and simultaneous nitrification-denitrification indiciated that a sludge retention time of 50 to 66 days, dissolved oxygen of $0.65 \mathrm{mg} / \mathrm{L}$, where nitrate accumulation was $95 \%$ [53].

Mourad et al. looked at a phosphate fertilizer plant in Egypt and found a relationship in phosphate within the wastewater affects the environment, by measuring Ra-226 and Th-232 isotope discharge [54]. Gouider et al. found a relationship between fluoride and phosphate removal, where fluoride was removed between 97 and 98\% from a phosphoric acid/hydrofluoric acid and between 93 and 95\% from a phosphoric/hexafluorosilic acid, as compared to $82 \%$ for phosphoric acid alone [55].

Beline et al. developed four types of biological reactors were capable of treating piggery wastewater that $60-70 \%$ nitrogen is removed by nitrification/denitrification. When additional mechanical separation was added for treatment, $80 \%$ of phosphorous was removed from soils along with the removal of pathogenic bacteria [56].

Dechlorination. Mezohegyi et al. discovered that using an upflow stirred packed-bed reactor with a biological activated carbon system was able to have a successful conversion rate of azo dyes. It was determined that an azo dye declorization model included heterogeneous catalysis and biological degradation [57].

Combined aerobic-anaerobic treatment. Sponza and Demirden discovered that in a sequential anaerobic baffled reactor and an aerobic completely stirred reactor, total COD (98\%) and Kemicetine $(100 \%)$ removal efficiency with real pharmaceutical wastewater. Also, acute toxicity was reduced across the reactors [58].

Kochany and Lipczynska-Kochany concluded that using aerobic and anaerobic industrial wastewater saw a higher removal of formaldehyde and phenol by anaerobic removal as compared to aerobic treatment, as anaerobic treatment ranged within $70 \%$, while aerobic treatment was within the $40 \%$ range [59]. Yemashova et al. found a relationship with the decomposition of various azo dyes is determined by the conditions - anaerobic or aerobic conditions, the composition of the microbial community, and methods of reduction. Specifically, the methyl red was the only dye removed during aerobic conditions, as compared to anaerobic conditions was able to convert all dyes present [60].

Lopez et al. was capable of using both coagulation and flotation with the coagulant being alum and anionic polymer as flocculent for treating slaughterhouse wastewater. Removing efficiency was $94 \%$ when using $250 \mathrm{mg} / \mathrm{L}$ alum, $51 \mathrm{mg} / \mathrm{L}$ of polymer, with a $\mathrm{pH}$ of 4 . This is compared with the biological process using an anaerobic filter (AF) and sequencing batch reactor (SBR) where COD ranged $50-81 \%$, configured with optimum removal was $97 \%$ for hydraulic retention time (HRT) $20 \mathrm{~h}$ in the $\mathrm{AF}$ and $9 \mathrm{~h}$ in the SBR [61]. Abreau and Zaiat found that using an upflow anaerobic-aerobic reactor where the anaerobic reactor had an HRT of $10 \mathrm{~h}$ and COD reduction from 389 to $137 \mathrm{mg} / \mathrm{L}$. Using a combined, COD removal went from 259 to $93 \mathrm{mg} / \mathrm{L}$ with an HRT of $12 \mathrm{~h}$ (6 h of anaerobic and $6 \mathrm{~h}$ of aerobic [62]. 


\section{Anaerobic Treatment}

Anaerobic/anoxic reactors, filters. Lin et al. found that using oxic-anoxic fixed biofilm reactors (FBR) with porous ceramic sticks and plastic rings for swine wastewater, had a removal efficiency increase to $86-92 \%$ for $\mathrm{NH}_{4}-\mathrm{N}$ from $56-98 \%$ removal, when the ammonia nitrogen loading rate increased from $0.25 \mathrm{~kg} \mathrm{NH}-\mathrm{N} / \mathrm{m}^{3}$ d from $0.082 \mathrm{~kg} \mathrm{NH}-\mathrm{N} / \mathrm{m}^{3}$ d. Also, the authors observed $82 \%$ denitrification by means of bacteria and $98-100 \%$ of removal occurred in the denitrifying part of the FBR, where $\mathrm{NO}_{2}-\mathrm{N}$ was $2 \mathrm{mg} / \mathrm{L}$ and $\mathrm{NO}_{3}-\mathrm{N} 6 \mathrm{mg} / \mathrm{L}$ [63].

Puyol compared anaerobic degradation of 2,4-dichlorophenol among both an upflow anaerobic sludge blanket (UASB) and an expanded granular sludge with glucose, and determined that the loading rates determined the overall removal of 2,4-dicholorophenol (2,4-DCP) was higher in the UASB than the EGSB with efficiency rates of 75 and $84 \%$ respectively [64]. Satyanarayan et al. noticed that using the upflow anaerobic sludge blanket process is capable of treating herbal pharmaceuticals by removing COD (range 86.2-91.6\%), BOD (90.0-95.2\%), and SS (62.6-68.0\%, It was determined that using the system is capable of treating high strength wastewater within a six month time frame [65].

Freine et al. found that by using an anaerobic fluidized bed reactor removal was $92 \%$ when the pentachlororphenol (PCP) concentration was $1 \mathrm{mg} / \mathrm{L}$ and $70 \%$ for $6 \mathrm{mg} / \mathrm{L}$, having considered $\mathrm{pH}$, alkalinity, COD, and volatile acids. Treatment was within a $16 \mathrm{~L}$ reactor and completed using granular activated carbon [66]. Behera et al. found that an upflow anoxic bioreactor could removed COD and $\mathrm{NO}_{3}-\mathrm{N}$ where nitrification by ethanol was 78 to $98 \%$ as compared to tapioca starch which removed a ranged between 68 to $96 \%$ for removal [67].

Microorganism Presence. Ahn et al. studied a sequencing batch reactor and noticed that there is a relationship between organic loading the F/M relationship, as increasing organic loading increased F/M. In addition, the amount of Rhodocyclus bacteria counts peaked at low loading rates [68]. El-Gohary and Tawfik found by using coagulation/flocculation and sequencing batch reactor processes that the optimum parameters include color removal, $\mathrm{pH}$, magnesium chloride and lime concentration. In addition, COD, BOD, and TSS were removed at efficiencies greater than 61\% [69]. Guo et al., using a temperature of $30^{\circ}$, $\mathrm{pH}$ between 6.0 and 8.5 , and percent $\mathrm{NaCl}$ of $10-20 \%$ for wastewater treatment using Halomonas Sp. strain bacteria to treat using azo dye wastewater. Azo dye treatment found decholorination at $90 \%$ with a treatment time of $24 \mathrm{~h} \mathrm{[70].}$

Ebrahimi et al. used two bubble column sequencing batch reactors with artificial wastewater at 20, 30 , and $35^{\circ}$ Celsius. Determination was made in the first stage that Lepothrix sppwas present at $30^{\circ} \mathrm{C}$, while $20^{\circ}$ acetate was consumed in anaerobic condition and biological phosphorus removal by Rhodocyclacae-affiliating OUT 14 at 30 and $35^{\circ}$ Celsisus acetate was completed and phosphorus removal did not occur as high [71].

Anaerobic-aerobic, biosporption, digestion. Kim et al. used a sequencing anoxic/anaerobicaerobic membrane bioreactor for 60 days where it was capable of having high efficiency removal of $\mathrm{COD}, \mathrm{TN}, \mathrm{TP}$, with the values greater than $70 \%$. Included the authors were capable of removing estrogenic compounds bisphenol A and 2,4-dicholorophenol [72]. 
Nagda et al. studied batch experiments, concluding the removal of Tendu leafe Diospyros melanoxylon within industrial waste treatment was capable of being adsorbed with the combination of biosorption and hydrogen peroxide. In addition, the authors concluded that the adsorption was favorable and could be summarized using Freundlich and Langmuir isotherms as similar to Congo red adsorption [73].

\section{Air Emissions}

Separation. Isolongifolene was converted from isolongifolene by means of membrane based air separation with oxygen enriched air were the derivative was related to reaction temperature and oxygen-enabled air, as observed by Wu et al. Maximum yield occurred was $39.1 \%$ and a temperature of $60^{\circ}$ Celsius. This minimized effluent discharge [74].

Model. Vijayaraghavan et al. concluded that through a three-dimensional Eulerian Community Multiscale Air Quality Model (CMAQ) for coal-fired power plants and emission of nitrates and sulfates in southeastern United States at the Escambia Bay and the watershed model on the Florida-Alabama border. The results indicated an effect on the concentration of nitrates and sulfur dioxide control on nitrogen deposition can be combined by the results of the nitrates and sulfates on oxidized nitrogen and reduced nitrogen species [75]. Corsi and Lin developed a model based on the component within latex paint, 2,2,3-trimethyl-1,3-pentanediol monoisobutyrate, compiling past history on emissions, recovery and factors affecting the process, and information on models describing the emissions [76].

Lopez-Torres and Llonens found that treating organic fraction municipal solid waste , 11.5\% COD was solubilized, using a loading rate of $0.15 \mathrm{~m}^{3} \mathrm{CH}_{4} / \mathrm{kg}$ volatile solids, removed soluble COD of $93.0 \%$ and $94 \%$ when treating using an anaerobic digester and lime addition $\mathrm{Ca}(\mathrm{OH})_{2}$ chemical pretreatment [77]. Whitcombe et al. found that using a fluidized bed model (FBR) with a Fluidized Catalytic Cracker Limit (FCCU) on a 1:8.5/ system. A conclusion was poor correlation between emission rates predicted, where this was done without the estimation of volatilization and flocculation for total emissions since it was able to achieve particle emission [78]. Gao et al. conducted a model known as backwards Lagrangian Stochestic Model (LSM) for methane emissions from multiple sources on a farm. The model consisted of $\mathrm{C} 1$, ground level sources, three wind-flow disturbances; $\mathrm{C} 2$, three sources with different emissions; $\mathrm{C} 4$, ground level and two elevate $4 \mathrm{~d}$ sources. The results found that the model provides accurate [79].

Biofilter. Cheng used a biological aerated filter with a fixed-film process, removed volatile organic compounds such as toluene, trimethylbenzene from a multiple layer ceramic capacitor manufacturing plant, and determined that $90 \%$ COD was removed, including a $30-40 \%$ toluene was aerated [80].

\section{Soils and Groundwater}

Soil Washing. Villa et al. found that by using solar photo-Fenton processes within $6 \mathrm{~h}$, 99\% DDT , 95\% DDE, and 100\% diesel removed; using Triton-X-100, removal was 66\% DDT, $80 \%$ DEE, and 100\% diesel. All metals $\mathrm{Pb}, \mathrm{Cr}, \mathrm{Ni}, \mathrm{Cu}, \mathrm{Cd}, \mathrm{Mn}$, and $\mathrm{Co}$ where below the Brazilian legislation wastewater concentrations [81]. Goi and Trapido were able to degrade chlorophenols up to 
$80 \%$ by using soil remediation at natural soil $\mathrm{pH}$ with calcium and magnesium peroxide. The authors found that this soil remediation process was comparable to application of hydrogen peroxide [82].

Adsorption. $\mathrm{Xu}$ et al. discovered that pharmaceuticals and personal care product (PPCPs) removal by adsorption was under Freundlich isotherms. Degradation within four US agricultural soils provided a trend where the PPCPs were removed within first-order exponential decay kinetics. In addition, the authors noted that the degradation that occurred within the system was in relation to the chemical composition within the soil, as higher rates of degradation occurred with lower chemical concentrations [83]. Zhang et al. found that the use of polymeric adsorption in aqueous solutions where the matrix of acrylic ester resin and functional groups determined the mechanism of adsorption. Also, the authors found high adsorption was contingent on high specific area and intense micropore structure [84]. Fan and Zhang found that using heat treatment for waste treatment of organic dyes was capable of removing alkaline-black were parameters: $\mathrm{pH}$ and adsorbentdose. Dye removal follows Langmuir adsorption isotherm model [85]. Niinane found that using chelating (S,S,S)-ethylenediominedisuccinc acid (EDDS) for electrokinetic process, and ethylenediaminetetraacetic acid (EDTA) and citric acid for soil washing, was capable of removing $50 \%$ of lead by means of soil washing and citric acid. However, using electrokinetics, EDTA was better at removing than EDDS [86].

Degradation performance (biodegradation), microorganisms. Jechalke et al. used coconut fiber and polypropylene textiles to treat benzene, methylene tert-butyl ether (MTBE), and ammonium by using a time of 14 months of operation. The results found that benzene was reduced from $20 \mathrm{mg} / \mathrm{L}$ to $1 \mu \mathrm{g} / \mathrm{L}$ MTBE $4 \mathrm{mg} / \mathrm{L}$ to $1.2 \mathrm{mg} / \mathrm{L}$, and ammonium went from $59 \mathrm{mg} / \mathrm{L}$ to $56 \mathrm{mg} / \mathrm{L}$, where the microorganisms used the coconut fiber and polypropylene textiles for degrading biofilms [87].

Beler-Baykal and Allar determined that using real and simulated fertilizer wastewater (using clinoptilolile) is capable of being used for the purpose of removing ammonium, where it was determined that ammonium removal was contingent on $\mathrm{pH}$ and contact times. Ideally, the authors were able to obtain surface capacities of greater than $14 \mathrm{mg} \mathrm{NH}_{4}-\mathrm{N} / \mathrm{g}$ clinoptilolite with empty bed contact times greater than $10 \mathrm{~min}$ [88]. Wang et al. discovered that mixed microbial indigenous bacteria are capable of biodegrading diesel and crude oil, n-alkanes, and polyaromatic hydrocarbons in the Yellow River Delta. The parameters affected were temperature, salinity, $\mathrm{pH}$, and Carbon:Nitrogen:Phosphorus (C:N:P) ratio [89].

Surfactants, Fe(zero valence Fe). Reinsch et al. found that nanoscale zerovalent iron (ZVI) applied to $10 \mathrm{mM}$ anions $\mathrm{Cl}^{-}, \mathrm{NO}_{3}{ }^{-}, \mathrm{SO}_{4}{ }^{2-}, \mathrm{HPO}_{4}{ }^{2-}, \mathrm{HCO}_{3}{ }^{-}$, and $9 \mathrm{mg} / \mathrm{L}$ dissolved oxygen. From the experiment, 1 month aging anions were dissolved by NZVI, 6 months was results showed all anions dissolved except nitrate, where 1 month had $\mathrm{Fe}$ and $\mathrm{FeSO}_{4}{ }^{2-}$, and 6 months had $\mathrm{Fe}_{3}\left(\mathrm{PO}_{4}\right)_{2} 8 \mathrm{H}_{2} \mathrm{O}$ (viviante) and iron sulfate, and $\left(\mathrm{Fe}_{16}\right)_{3}+\mathrm{O}_{16} \mathrm{OH}_{\text {, }} \mathrm{SO}_{4}\left(12-13,(10-12) \mathrm{H}_{2} \mathrm{O}\right.$ [90].

Thompson et al. used nanoscale zero-valent iron to degrade alachior herbicide and determined that a surface area of $25 \mathrm{~m}^{2} / \mathrm{g}$ was sufficient, while a surface area between 1-2 $\mathrm{m}^{2} / \mathrm{g}$ surface area constants were $38.5 \times 10^{-5}$ and $3.8-7.7 \times 10^{-5} \mathrm{~L} / \mathrm{hm}^{2}$ [91]. Noubactep et al. compared the shaking intensity under various conditions for the purpose of discoloring methylene blue with metallic iron, where it was determined that the materials considered were scrap iron, granular activated carbon, and deep sea manganese nodules. From fifty days of experimentation, discoloration of methylene blue is related to shaking intensity, where the peak shaking intensity is $50 \mathrm{~min}^{-1}$ [92]. 
Liu et al. was capable of degrading 2,2,',4,4'-tetrabromodiphenye ether (BDE, 47) consisting of soil-washing and photodestruction processes within non-ionic surfactants under UV-irradation at $253.7 \mathrm{~nm}$. From considering concentration, $\mathrm{pH}$, cation and acetone, it was found that the results followed pseudo-first-order kinetics, where $\mathrm{pH}$ is varied because of the cations and acetone [93].

In situ applications. Lim and Lynch found that using a photocatalytic reactor was capable of designing in an in-situ groundwater remediation, and having five successful experiments, a hydraulic retention time (HRT) of 1 day, average water velocity of $0.21 \mathrm{~m} / \mathrm{d}$ for high efficiency of using this particular design [94].

Other methods, models. Chen et al. discusses a mathematical model that transports reagent within vertical circulation flow within an anisotropic aquifer for the purpose to enhance groundwater remediation in an anisotropic aquifer with vertical circulation well technology. The following methods are used-analytical solution for steady state drawdown near a vertical circulation well, radial and vertical components are applied to 3-D axismetrical advection dispersion in cylindrical coordinates [95].

Lin et al. considered a simulated biotreatment process specifically biostimulation and bioagumentation with oxygen-related reactive barriers (ORRB) and water. The authors discovered that benzene, toluene, ethylene, zylene (BTEX) remove decreases at a concentration of $30 \mathrm{mg} / \mathrm{L}$, where ORRB removal was higher for nitrogen-added for biostimulation, specifically oxygen content was inversely proportion to the distance from ORRB [96].

Davie et al. found that trichloroethylene (TCE) removal (500 to $1200 \mathrm{mg} / \mathrm{L}$ ) at Edwards Air Force Base in California was at $99.8 \%$ at $4 \mathrm{~h}$ when considering catalytic reductive dechlorination (CRD) for groundwater pumped at $2 \mathrm{gal} / \mathrm{min}$, hydrogen concentration of $0.35 \mathrm{mg} / \mathrm{L}$ with $2-3 \mathrm{~min}$ pumping and a $20 \mathrm{~kg}$ shell, a pH of 7 on aluminum bed with a $2 \%$ by weight [97]. Finzger and Lestan considered soil remediation using EDTA for leaching and electrochemical advanced oxidation (EAOP) and soil rinsing, using a boron dipped anode removed 44\% Lead $(\mathrm{Pb}), 14 \% \mathrm{Zinc}(\mathrm{Zn})$, and 55\% Cadmium $(\mathrm{Cd})$ from the soul. The results found optimum at $\mathrm{pH}$ of $7.73,13.74 \mathrm{~Pb}, \mathrm{Zn} 1007 \mathrm{mg} / \mathrm{kg}$, and $\mathrm{Cd}$ $9.1 \mathrm{mg} / \mathrm{kg}[98]$.

\section{Reuse}

Photocatalysis. Sanchez et al. found that grey water, waste produced from hotel wastes, where the reuse was capable of obtaining $65 \%$ dissolved organic removal after $150 \mathrm{~min}$ by the application of photocatalysis over titanium dioxide. Specific constituents include ionic surfactants from personal care products and laundry detergents [99]. Zho and Zhu compared the treatment efficiency of various advanced oxidation processes $\left(\mathrm{UV} / \mathrm{O}_{3}, \mathrm{UV} / \mathrm{TiO}_{2}\right.$, and $\left.\mathrm{UV} / \mathrm{TiO}_{2} / \mathrm{O}_{3}\right)$ using laboratory scale recirculation ozonation photocatlytic system. Ozone and the photocatalytic process $\left(\mathrm{UV} / \mathrm{TiO}_{2} / \mathrm{O}_{3}\right)$ is more efficient in TOC removal for TOC, where one must consider ozone dose and ozone procedure had a higher impact than UV intensity, incoming ozone flow rate, and UV light source [100]. Riera-Torres et al. found that when comparing nanofiltration using a $0.5 \mathrm{~L}$ membrane at 10 bar, versus coagulation-flocculation with anionic polyelectrolyte flocculant and $\mathrm{FeCl}_{3}$ as a coagulant, and melamine-urea-formaldehyde and polyamine resins, $40-80 \%$ of color in 5 dyes was removed, as compared to using coagulation-flocculation which removed $85-95 \%$ color within 4 dyes [101]. 
RO-IE (reverse osmosis/ion exchange), membranes. Yangali-Quintanilla et al. found that nanofiltration and reverse osmosis was capable of being strong treatment for pharmaceuticals, pesticides, endrocrine disruptions, and organic compounds, removing $82 \%$ by nanofiltration and $85 \%$ by reverse osmosis. Ionic compound removal was discovered at $97 \%$ and $99 \%$ by nanofiltration and reverse osmosis respectively [102]. Zhu and Zou used activated carbon with $\mathrm{TiO}_{2}$ nanoparticles with a sol-gel method and concluded that photocatalytic process was able to decompose compounds by means of using $\mathrm{H}_{2} \mathrm{O}_{2}$ and ultrasound. The components considered using UV light source, UV irridiation, hydrogen peroxide and ultrasound constituent [103].

Authors Bellona et al. compared the efficiency of using both an ultralow pressure reverse osmosis (ULPRO) and ultrafiltration both at pilot scale and full-scale in California. The conclusion from the tests based on operation, total organic carbon (TOC), total nitrogen (TN), and regulated and unregulated organic pollutants was that the treatment process did meet water quality requirements [104]. Juang et al. found that a membrane-based ultrafiltration and reverse osmosis process was capable of completely adhering to water standards for tap, cooling, and boiling water, and feed water for a purification machine. When treating mechanical polishing wastewater. However, when UF pretreatment only removed $42-46.9 \%$ conductivity, $98.1-99.4 \%$ turbidity, and $4.5-24.5 \%$ TOC, while RO only reduced conductivity to $6 \mathrm{mu} \mathrm{S} / \mathrm{cm}, 0.01 \mathrm{NTU}$, and $1.6 \mathrm{mg} / \mathrm{L}$ TOC [105].

Dialysis, sludge reuse. Vertova et al. found elctrodialysis for treating light carboxylic acids from an acidic waste stream. In addition, the authors determine that the use of electrodialysis is a sustainable alternative to biological degradation [106].

Kim et al. concluded that using $\mathrm{O}_{3}, \mathrm{UV} / \mathrm{H}_{2} \mathrm{O}_{2}$, and $\mathrm{O}_{3} / \mathrm{UV}$ treatment processes with pharmaceuticals and personal care products and it was shown that using $\mathrm{O}_{3} / \mathrm{UV}$ and $\mathrm{UV} / \mathrm{H}_{2} \mathrm{O}_{2}$ treatments are recommended and also profitable due to the issues of bromated formation that occurs when using ozone [107]. Bello et al. completed a study where a sewage treatment plant with aeration, an activated sludge and compost water treatment within metallurgic industry. Parameters investigated include $\mathrm{pH}$, turbidity, color, aerobic bacteria, free chlorine, hardness, alkalinity, chloride, sulfates, and dissolved total solids (TDS) for the purpose of removing biological oxygen demand (BOD), chemical oxygen demand (COD), and suspended solids (SS) [108].

Disinfection. When using disinfection in grey water, authors Winward et al. discovered that particleassociated coliforms (PAC) having come into contact with chlorine disinfection show that the $91 \%$ of the total coliforms were particle related, where the disinfection efficiency was based on particle size. Those PAC were not removed due to larger-sized particles shielding them from being removed [109].

\section{Summary}

Over the last three years there have been various new treatment methods that have been used. For example, nano-alumina, PS-EDTA, and beta-cyclodetrin are some of the new materials for sorption. Several authors introduced new methods of treatment, which include a new biological and electrochemical (BEO) treatment within physicochemical method using boron-diamond electrodes for pesticide wastewater, and ion exchange usage for treating zirconium radioactive waste. Ozone has been effective in various realms of treatment-removing organic compounds, pharmaceuticals, and 
dyes. Nitrification-denitrification and sequencing batch reactor remains a popular method of treating nutrients and dometic wastewater respectively. Adsorption is a commonly used method for dyes, pharmaceuticals, and heat transfers. Finally, treatment of grey water is significant due to its ability for reuse by various industries. Treatment of grey water varies using various photocatalysis methods - ultraviolet (UV), ozone $\left(\mathrm{O}_{3}\right)$, and hydrogen peroxide $\left(\mathrm{H}_{2} \mathrm{O}_{2}\right)$, membrane process (nanofiltration, ultrafiltration, and reverse osmosis), and electrodialysis.

\section{Conclusion}

While this is not an all-encompassing text for the last three years, this summary does provide an opportunity to consider what treatment methods are being used within subjects surrounding waste handling and reuse related to wastes from chemicals and allied products. As many technological advances have been made to consider more effective methods, future research will be employed for the purpose of improving current methods or proposing new methods beyond the scope of what is currently and readily available.

\section{References}

1. Devi, P.S.R.; Joshi, S.; Verma, R.; Reddy, A.V.R.; Lali, A.M.; Gabntayet, L.M. Ion-Exchange Separation of Co-60 and Sb-125 from Zirconium for Radioactive Management. Nucl. Tech. 2010, 171, 220-227.

2. Ko, G.; Simmons, O.D.; Likirdopulos, C.A., III; Worley-Davis, L.; Williams, M.; Sobsey, M.D.; Investigation of Bioaerosols Released from Swine Farms using Conventional and Alternative Waste Treatment and Management Technologies. Environ. Sci. Technol. 2008, 42, 8849-8857.

3. Cobo, M.; Conesa, J.A.; Montes de Correa, C. Effect of the reducing agent on the hydrodechlorination of dioxins over 2 wt.\% Pd/gamma-Al2O3. Appl. Catal. B. 2009, 92, 367-376.

4. Schiffman, S.S.; Graham, B.G.; Williams, C.M. Dispersion modeling to compare alternative technologies for odor remediation at swine facilities. J. Air Waste Manage. Assoc. 2008, 58, 1166-1176.

5. Muhle, S.; Balsam, I.; Cheeseman, C.R. Comparison of carbon emissions associated with municipal solid waste management in Germany and the UK. Resour. Conservat. Recycl. 2010, 54, 793-801.

6. Roudil, D.; Bonhoure, J.; Pik, R.; Cuney, M.; Jegou, C.; Gauthier-Lafaye, F. Diffusion of radiogenic helium in natural uranium oxides. J. Nucl. Mater. 2008, 378, 70-78.

7. Davoli, E.; Fattore, E.; Paiano, V.; Colombo, A.; Palmiotto, M.; Rossi, A.N.; Il Grande, M.; Fanelli, R. Waste management health risk assessment: A case study of a solid waste landfill in South Italy. Waste Manag. 2010, 30, 1608-1613.

8. Othman, N.; Basri, N.E.A.; Yunus, M.N.M.; Sidek, L.M.; Othman, N.A. Potential of electronic plastic waste as a source of raw material and energy recovery. Sains Malaysiana. 2009, 38, 707-715.

9. Zhang, L.; Dong, L.S.; Zhou, L.; Zhang, T.; Huang, Y. Organochlorine pesticides contamination in surface soils from two pesticide factories in southeast china. Chemosphere 2009, 77, 628-633. 
10. Zhang, H.; He, P.; Shao, L. Implication of heavy metals distribution for a municipal solid waste management system - a case study in Shanghai. Sci. Total Environ. 2008, 402, 257-267.

11. Astrup, T.; Fruergaard, T.; Christensen, T.H. Recycling of plastic: Accounting of greenhouse gases and global warming contributions. Waste Manage. Res. 2009, 27, 763-772.

12. Homem, V.; Alves, A.; Santos, L. Amoxicillin removal from aqueous matrices by sorption with almond shell ashes. Int. J. Environ. Anal. Chem. 2010, 90, 1063-1084.

13. Bhatnagar, A.; Kumar, E.; Sillanpaa, M. Nitrate removal from water by nano-alumina: Characterization and sorption studies. Chem. Eng. J. 2010, 163, 317-323.

14. Wang, X.; Zhang, B.; Shen, Z.; Qiu, Z.; Chen, Z.; Jin, M.; Li, J.; Wang, J. The EPS characteristics of sludge in an aerobic granule membrane bioreactor. Bioresour. Technol. 2010, $21,8046-8050$.

15. Cheng, W.H. Using a biological aerated filter to treat mixed water-borne volatile organic compounds and assessing its emissions. J. Enviro. Sci. 2009, 21, 1497-1502.

16. Mori, M.; Cassella, R.J. Sorption of crystal violet by polyurethane foam from aqueous medium containing sodium dodecylsulfate. Quimica Nova. 2009, 32, 2039-2045.

17. Li, N.; Mei, Z.; Chen, S. Removal of 4-Chlorophenol from Aqueous Solutions by Cyclodextrin Polymer. Frensius Environ. Bull. 2009, 18, 2249-2253.

18. Zheng, H.; Zhu, G.; He, Q.; Hu, P.; Jiao, S.; Tshukudu, T.; Zhang, P. A study on the degradation of direct pink by the low-frequency ultrasonic irradiation. Water Sci. Technol. 2010, 62, 829-836.

19. Katuri, K.P.; Mohan, S.V.; Sridhar, S.; Pati, B.R.; Sarma, P.N. Laccase-membrane reactors for decolorization of an acid azo dye in aqueous phase: Process optimization. Water Res. 2009, 43, 3647-3658.

20. Hasal, P.; Penizkova, R. Penicillin G splitting in a flow-through electro-membrane reactor with the membrane-bound enzyme. Asia-Pacific J. Chem. Eng. 2009, 4, 356-364.

21. Saravanane, R.; Sundararaman, S. Effect of loading rate and HRT on the removal of cephalosporin and their intermediates during the operation of a membrane bioreactor treating pharmaceutical wastewater. Environ. Technol. 2009, 30, 1017-1022.

22. Mohan, S.V.; Mohanakrishna, G.; Reddy, B.P.; Saravanan, R.; Sarma, P.N. Bioelectricity generation from chemical wastewater treatment in mediatorless (anode) microbial fuel cell (MFC) using selectively enriched hydrogen producing mixed culture under acidophilic microenvironment. Biochem. Eng. J. 2008, 39, 121-130.

23. Beler-Baykal, B.; Allar, A.D. Upgrading fertilizer production wastewater effluent quality for ammonium discharges through ion exchange with clinoptilolite. Environ. Technol. 2008, 29, 665-672.

24. Ruan, X.; Liu, M.; Zeng, Q.; Ding, Y. Degradation and decolorization of reactive red X-3B aqueous solution by ozone integrated with internal micro-electrolysis. Separ. Purif. Tech. 2010, 74, 195-201.

25. Gulnaz, O. Adsorption of Reactive Dyes from Aqueous Solution by Chara Vulgaris. Frensius Environ. Bull. 2009, 18, 2243-2248.

26. Turhan, K.; Turgut Z. Treatment and degradability of direct dyes in textile wastewater by ozonation: A laboratory investigation. Desalination Water Treat. 2009, 11, 184-191. 
27. Merle, T.; Pic, J.S.; Manero, M.H.; Debellefontaine, H. Enhanced bio-recalcitrant organics removal by combined adsorption and ozonation. Water Sci. Technol. 2009, 60, 2921-2928.

28. Wang, C.; Xi, J.H.H.; Hu, H.; Yao, Y. Stimulative effects of ozone on a biofilter treating gaseous chlorobenzene. Environ. Sci. Technol. 2009, 43, 9407-9412.

29. Garoma, T.; Matsumoto, S.A.; Wu, Y.; Klinger, R. Removal for Bisphenol A and its Reaction-Intermediates from Aqueous Solution by Ozonation. Ozone-Sci. Eng. 2010, 32, 338-343.

30. Gagnon, C.; Lajeunesse, A.; Cejka, P.; Gagne, F.; Hausler, R. Degradation of selected acidic and neutral pharmaceutical products in a primary-treated wastewater by disinfection processes. Ozone-Sci. Eng. 2008, 30, 387-392.

31. Di Iaconi, C.; Del Moro, G.; de Sanctis, M.; Rossetti, S. A chemically enhanced biological process for lowering operative costs and solid residues of industrial recalcitrant wastewater treatment. Water Res. 2010, 44, 3635-3644.

32. Xiao, H.; Xu, Y.; Yu, M.; Zhang, Q. Enhanced mineralization of 2,4-dichlorophenol by ozone in the presence of trace permanganate: Effect of pH. Environ. Technol. 2010, 31, 1295-1300.

33. Polo-Sanchez, M.; Rivero, M.J.; Ortiz, I. Photocatalytic oxidation of grey water over titanium dioxide suspensions. Desalination. 2010, 262, 141-146.

34. Naddeo, V.; Meric, S.; Kassinos, D.; Belgiorno, V.; Guida, M. Fate of pharmaceuticals in contaminated urban wastewater effluent under ultrasonic irradiation. Water Res. 2009, 43, 4019-4027.

35. Wang, W.; Irawan, A.; Ku, Y. Photocatalytic degradation of Acid Red 4 using a titanium dioxide membrane supported on a porous ceramic tube. Water Res. 2008, 42, 4725-4732.

36. $\mathrm{Wu}, \mathrm{H}$; $\mathrm{Li}, \mathrm{C}$. Kinetic study of phenol recovery using phase-transfer catalysis in horizontal membrane reactor. Chem. Eng. J. 2008, 144, 502-508.

37. Zhou J.; Duan, S.H.; Chen, Y.; Hu, B. Nitrogen removal efficiency of iron-carbon micro-electrolysis system treating high nitrate nitrogen organic pharmaceutical wastewater. J. Cent. S. Univ. Tech. 2009, 16, 368-373.

38. Prieto, A.; Araujo, L.; Navalon, A.; Vilchez, J.L. Comparison of solid-phase extraction and solidphase microextraction using octadecylsilane phase for the determination of pesticides in water samples. Curr. Anal. Chem. 2009, 5, 219-224.

39. Wang, K.; Liu, S.; Zhang, Q.; He, Y. Pharmaceutical wastewater treatment by internal micro-electrolysis-coagulation, biological treatment and activated carbon adsorption. Environ. Technol. 2009, 30, 1469-1474.

40. Han, G.C.; Liu, Z.; Wang, Y.L. Preparation and application of pharmaceutical wastewater treatment by praseodymium doped $\mathrm{SnO} 2 / \mathrm{Ti}$ electrocatalytic electrode. J. Rare Earth. 2008, 26, 532-537.

41. Liu, Y.; Moy, B.; Kong, Y.; Tay, J. Formation, physical characteristics and microbial community structure of aerobic granules in a pilot-scale sequencing batch reactor for real wastewater treatment. Enzyme Microb. Technol. 2010, 46, 520-525.

42. Yang, Y.; Wang, P.; Shi, S.; Liu, Y. Microwave enhanced fenton-like process for the treatment of high concentration pharmaceutical wastewater. J. Hazard. Mater. 2009, 168, 238-245. 
43. Mozia, S.; Morawski, A.W.; Toyoda, M.; Inagaki, M. Effectiveness of photodecomposition of an azo dye on a novel anatase-phase $\mathrm{TiO} 2$ and two commercial photocatalysts in a photocatalytic membrane reactor (PMR). Separ. Purif. Tech. 2008, 63, 386-391.

44. Heger, S.F.; Schmidt, D.R.; Janni, K.A. Aerobic and Media Filter Treatment Systems for Milk House Wastewater on Small Dairy Operations. Appl. Eng. Agric. 2010, 26, 319-327.

45. You, S.; Teng, J. Performance and dye-degrading bacterial isolation of a hyrbid membrane process. J. Hazard. Mater. 2009, 172, 172-179.

46. Wang, X.; Gai, L.; Sun, X.; Xie, H.; Gao, M.; Wang, S. Effects of long-term addition of Cu(II) and $\mathrm{Ni}(\mathrm{II})$ on the biochemical properties of aerobic granules in sequencing batch reactors. Appl. Microbiol. Biotechnol. 2010, 86, 1967-1975.

47. Moussavi, G.; Barikbin, B.; Mahmoudi, M. The removal of high concentrations of phenol from saline wastewater using aerobic granular SBR. Chem. Eng. J. 2010, 158, 498-504.

48. Esteve, K.; Poupot, C.; Mietton-peuchot, M.; Milisic, V. Degradation of pesticide residues in vineyard effluents by activated-sludge treatment. Water Sci. Technol. 2009, 60, 1885-1894.

49. Hussain, S.; Siddique, T.; Saleem, M.; Arshad, M.; Khalid, A. Impact of Pesticides on Soil Microbial Diversity, Enzymes, and Biochemical Reactions. Adv. Agron. 2009, 102, 159-200.

50. Christian, S.J.; Grant, S.R.; Singh, K.S.; Landine, R.C. Performance of a high-rate/high-shear activated sludge bioreactor treating biodegradable wastewater. Environ. Technol. 2008, 29, 837-846.

51. Yuan, X.; Gao, D. Effect of dissolved oxygen on nitrogen removal and process control in aerobic granular sludge reactor. J. Hazard. Mater. 2010, 178, 1041-1045.

52. Zeng, W.; Li, L.; Yang, Y.Y.; Wang, S.Y.; Peng, Y.Z. Nitrification and denitrification of domestic wastewater using a continuous anaerobic-anoxic-aerobic $(\mathrm{A}(2) \mathrm{O})$ process at ambient temperatures. Bioresour. Technol. 2010, 101, 8074-8082.

53. Guo, J.; Peng, J.; Wang, S.Y.; Zheng, Y.A.; Huang, H.J.; Wang, Z.W. Long-term effect of dissolved oxygen on partial nitrification performance and microbial community structure. Bioresour. Technol. 2009, 100, 2796-2802.

54. Mourad, N.M.; Sharshar, T.; Elnimr, T.; Mousa, M.A. Radioactivity and fluoride contamination derived from a phosphate fertilizer plant in Egypt. Appl. Radat. Isot. 2009, 67, 1259-1268.

55. Gouider, M.; Feki, M.; Sayadi, S.; Separative recovery with lime of phosphate and fluoride from an acidic effluent containing $\mathrm{H}_{3} \mathrm{PO}_{4}$, $\mathrm{HF}$ and/or $\mathrm{H}_{2} \mathrm{SiF}_{6}$. J. Hazard. Mater. 2009, 171, 962-968.

56. Beline, F.; Daumer, M.L.; Loyon, L.; Pourcher, A.M.; Dabert, P.; Guiziou, F.; Peu, P. The efficiency of biological aerobic treatment of piggery wastewater to control nitrogen, phosphorus, pathogen and gas emissions. Water Sci. Technol. 2008, 57, 1909-1914.

57. Mezohegyi, G.; Fabregat, A.; Font, J.; Bengoa, C.; Stuber, F.; Fortuny, A. Advanced bioreduction of commercially important azo dyes: Modeling and correlation with electrochemical characteristics. Ind. Eng. Chem. Res. 2009, 48, 7054-7059.

58. Sponza, D.T.; Demirden, P. Relationships between chemical oxygen demand (COD) components and toxicity in a sequential anaerobic baffled reactor/aerobic completely stirred reactor system treating Kemicetine. J.Hazard. Mater. 2010, 176, 64-75. 
59. Lipczynska-Kochany, E.; Kochany, J. Humic substances in bioremediation of industrial wastewater-Mitigation of inhibition of activated sludge caused by phenol and formaldehyde. $J$. Environ. Sci. Health, Part A: Toxic/Hazard. Subst. Environ. Eng. 2008, 43, 619-626.

60. Yemashova, N.A.; Kotova, I.B.; Netrusov, A.I.; Kalyuzhnyi, S.V. Special traits of decomposiiton of azo yes by anaerobic microbial communities. Appl. Biochem. Microbiol. 2009, 45, 176-181.

61. Lopez, A.; De La Barrera Fraire, J.; Vallejo Rodriguez, R.; Barahona Argueta, C. Comparative study between a physicochemical and a biological process to treat slaughterhouse wastewater. Interciencia. 2008, 33, 490-495.

62. Abreu, S.B.; Zaiat, M. Performance of Anaerobic-Aerobic Packed-Bed Reactor in the Treatment of Domestic Sewage. Engenharia Sanitaria E Ambiental. 2008, 13, 181-188.

63. Lin, Y. Nitrification/denitrification in swine wastewater using porous ceramic sticks with plastic rings as supporting media in two-stage fixed-biofilm reactors. Water Sci. Tech. 2010, 62, 985-994.

64. Puyol, D.; Mohedano, A.F.; Sanz, J.L.; Rodriguez, J.J. Comparison of UASB and EGSB performance on the anaerobic biodegradation of 2,4-dichlorophenol. Chemosphere. 2009, 76, 1192-1198.

65. Satyanarayan, S.; Karambe, A.; Vanerkar, A.P. Herbal pharmaceutical wastewater treatment by a pilot scale upflow anaerobic sludge blanket (UASB) reactor. Water Sci. Technol. 2009, 59, 2265-2272.

66. Freire, F.B.; Pires, E.C.; Freire, J.T. Anaerobic Treatment of Pentachlorophenol in a Fluidized Bed Reactor Fed with Synthetic Wastewater Containing Glucose as a Single Carbon Source. Engenharia Sanitaria E Ambiental 2008, 13, 339-346.

67. Behera, S.K.; Rene, E.R.; Murthy, D.V.S. Performance of upflow anoxic bioreactor for wastewater treatment. Int. J. Environ. Sci. Tech. 2008, 4, 247-252.

68. Ahn, C.H.; Park, J.K.; Wang, J. Changes in polyhydroxy-alkanoates (PHAs) during enhanced biological phosphorus removal with dairy industrial wastewater J. Environ. Eng. 2009, 135, 1213-1220.

69. El-Gohary, F.; Tawfik, A. Decolorization and COD reduction of disperse and reactive dyes wastewater using chemical-coagulation followed by sequential batch reactor (SBR) process. Desalination. 2009, 249, 1159-1164.

70. Guo, J.; Zhou, J.; Wang, D.; Tian, C.; Wang, P.; Uddin, M. S. A novel moderately halophilic bacterium for decolorizing azo dye under high salt condition. Biodegradation. 2008, 19, 15-19.

71. Ebrahimi, S.; Gabus, S.; Rohrbach-Brandt, E.; Hosseini, M.; Rossi, P.; Maillard, J.; Holliger, C. Performance and microbial community composition dynamics of aerobic granular sludge from sequencing batch bubble column reactors operated at 20 A degrees $\mathrm{C}, 30 \mathrm{~A}$ degrees $\mathrm{C}$, and $35 \mathrm{~A}$ degrees C. Appl. Microbiol. Biotechnol. 2010, 87, 1555-1568.

72. Kim, I.H.; Yamashita, N.; Kato, Y.; Tanaka, H. Discussion on the application of $\mathrm{UV} / \mathrm{H}_{2} \mathrm{O}_{2}, \mathrm{O}_{3}$ and $\mathrm{O}_{3} / \mathrm{UV}$ processes as technologies for sewage reuse considering the removal of pharmaceuticals and personal care products. Water Sci. Technol. 2009, 59, 945-955.

73. Nagda, G.K.; Ghole, V.S. Biosorption of Congo Red by hydrogen peroxide treated tendu waste. Iranian J. Environ. Health Sci. Eng. 2009, 6, 195-200. 
74. Wu, F.; Xu, Z.; Wang, Z.; Shi, Y.; Li, L. Zhang, Z. Membrane-based air separation for catalytic oxidation of isolongifolene. Chem. Eng. J. 2010, 158, 426-430.

75. Vijayaraghavan, K.; Seigneur, C.; Bronson, R.; Chen, S.; Karamchandani, P.; Walters, J.T.; Jansen, J.J.; Brandmeyer, J.E.; Knipping, E.M. A Case Study of the Relative Effects of Power Plant Nitrogen Oxides and Sulfur Dioxide Emission Reductions on Atmospheric Nitrogen Deposition. J. Air Waste Manage. Assoc. 2010, 60, 287-293.

76. Corsi, R.L.; Lin, C.C. Emissions of 2,2,4-Trimethyl-1,3-Pentanediol Monoisobutyrate (TMPD-MID) from Latex Paint: A Critical Review. Crit. Rev. Environ. Sci. Tech. 2009, 39, 1052-1080.

77. Lopez-Torres, M.; Espinosa Llorens, M.D.C. Effect of alkaline pretreatment on anaerobic digestion of solid wastes. Waste Manage. 2008, 28, 2229-2234.

78. Whitcombe, J.M.; Braddock, R.D.; Agranovski, I.E. Modeling and characterization of air emissions from laboratory and industrial fluidized beds. Chem. Eng. Technol. 2008, 31, 1336-1341.

79. Gao, Z.L.; Desjardins, R.L.; van Haarlem, R.P.; Flesch, T.K. Estimating Gas Emissions from Multiple Sources using a Backward Lagrangian Stochastic Model. J. Air. Waste Manag. Assoc. 2008, 58, 1415-1421.

80. Cheng, W.H. Using a Biological Aerated Filter to Treat Mixed Water-Borne Volatile Organic Compounds and Assessing its Emissions. J. Environ. Sci.-China. 2009, 21, 1497-1502.

81. Villa, R.D.; Trovo, A.G.; Nogueira, R.F.P. Soil Remediation using a Coupled Process: Soil Washing with Surfactant followed by Photo-Fenton Oxidation. J. Hazard Mater. 2010, 174, 770-775.

82. Goi, A.; Trapido, M. Chlorophenols Contaminated Soil Remediation by Peroxidation. J. Adv. Oxid. Technol. 2010, 13, 50-58.

83. $\mathrm{Xu}, \mathrm{J} . ; \mathrm{Wu}, \mathrm{L}$; Chang, A.C. Degradation and adsorption of selected pharmaceuticals and personal care products (PPCPs) in agricultural soils. Chemosphere 2009, 77, 1299-1305.

84. Zhang, Q.; Chen, J.; Li, A.; Yang, W. Adsorption mechanism of toxic organic compounds in chemical wastewater by polymeric adsorbents. Acta Polymerica Sinica 2008, 7, 651-655.

85. Fan, X.; Zhang, X. Adsorption properties of activated carbon from sewage sludge to alkaline-black. Mater. Lett. 2008, 62, 1704-1706.

86. Niinae, M.; Nishigaki, K.; Aoki, K. Removal of Lead from Contaminated Soils with Chelating Agents. Mater. Trans. 2008, 49, 2377-2382.

87. Jechalke, S.; Vogt, C.; Reiche, N.; Franchini, A.G.; Borsdorf, H.; Neu, T.R.; Richnow, H.H. Aerated treatment pond technology with biofilm promoting mats for the bioremediation of benzene, MTBE and ammonium contaminated groundwater. Water Res. 2010, 44, 1785-1796

88. Beler-Baykal, B.; Allar, A.D. Upgrading fertilizer production wastewater effluent quality for ammonium discharges through ion exchange with clinoptilolite. Environ. Technol. 2008, 29, 665-672.

89. Wang, Z.Y.; Gao, D.M.; Li, F.M.; Zhao, J.; Xin, Y.Z.; Simkins, S.; Xing B.S. Petroleum Hydrocarbon Degradation Potential of Soil Bacteria Native to the Yellow River Delta. Pedosphere 2008, 18, 707-716. 
90. Reinsch, B.C.; Forsberg, B.; Penn, R.L.; Kim, C.S.; Lowry, G.V. Chemical Transformations during Aging of Zerovalent Iron Nanoparticles in the Presence of Common Groundwater Dissolved Constituents. Environ. Sci. Technol. 2010, 44, 3455-3461.

91. Thompson, J.M.; Chisholm, B.J.; Bezbaruah, A.N. Reductive Dechlorination of Chloroacetanilide Herbicide (Alachlor) Using Zero-Valent Iron Nanoparticles. Environ. Eng. Sci. 2010, 27, 227-232.

92. Noubactep, C.; Kurth, A.F.; Sauter, M. Adsorption evaluation of the effects of shaking intensity on the process of methylene blue discoloration by metallic iron. J. Hazard. Mater. 2009, 169, 1005-1011.

93. Li, X.; Huang, J.; Fang, L.; Yu, G.; Lin, H.; Wang, L. Photodegradation of 2,2',4,4'-tetrabromodiphenyl ether in nonionic surfactant solutions. Chemosphere 2008, 73, 1594-1601.

94. Lim, L.L.P.; Lynch, R.J. A proposed photocatalytic reactor design for in situ groundwater applications. Appl. Catal. Gen. 2009, 378, 202-210.

95. Chen, J.; Jang, C.; Cheng, C.; Liu, C. Conservative solute approximation to the transport of a remedial reagent in a vertical circulation flow field. J. Hydrol. 2010, 390, 155-168.

96. Lin, C.; Chen, L.I.Y.; Lai, C. Microbial communities and biodegradation in lab-scale BTEX-contaminated groundwater remediation using an oxygen-releasing reactive barrier. Bioprocess Biosyst. Eng. 2010, 33, 383-391.

97. Davie, M.G.; Cheng, H.; Hopkins, G.D. Lebron, C.A.; Reinhard, M. Implementing Heterogeneous Catalytic Dechlorination Technology for Remediating TCE-Contaminated Groundwater. Environ. Sci. Technol. 2008, 42, 8908-8915.

98. Finzgar, N.; Lestan, $\mathrm{D}$. The two-phase leaching of $\mathrm{Pb}, \mathrm{Zn}$ and $\mathrm{Cd}$ contaminated soil using EDTA and electrochemical treatment of the washing solution. Chemosphere 2008, 73, 1484-1491.

99. Sanchez-Polo, M.; Lopez-Penalver, J.; Prados-Joya, G.; Ferro-Garcia, M.A. Rivera-Utrilla, J. Gamma irridation of pharmaceutical compounds, nitroimidazoles, as a new alternative for water treatment. Water Res. 2009, 43, 4028-4036.

100. Zou, L.; Zhu, B. The synergistic effect of ozonation and photocatalysis on color removal from reused water. J. Photochem. Photobiol. Chem. 2008, 196, 24-32.

101. Riera-Torres, M.; Gutierrez-Bouzan, C.; Crespi, M. Combination of coagulation-flocculation and nanofiltration techniques for dye removal and water reuse in textile effluents. Desalination 2010, 252, 53-59.

102. Yangali-Quintanilla, V.; Maeng, S.K.; Fujioka, T.; Kennedy, M.; Amy, G. Proposing nanofiltration as acceptable barrier for organic contaminants in water reuse. J. Membr. Sci. 2010, 362, 334-345.

103. Zhu, B.; Zou, L. Trapping and decomposing of color compounds from recycled water by $\mathrm{TiO}_{2}$ coated activated carbon. J. Environ. Manage. 2009, 90, 3217-3225.

104. Bellona, C.; Drewes, J.E.; Oelker, G.; Luna, J.; Filteau, G.; Amy, G. Comparing nanofiltration and reverse osmosis for drinking water augmentation. J. Am. Water Works Assoc. 2008, 100, 102-118. 
105. Juang, L.C.; Tseng, D.H.; Lin, H.Y.; Lee, C.K.; Liang, T.M. Treatment of chemical mechanical polishing wastewater for water reuse by ultrafiltration and reverse osmosism separation. Environ. Eng. Sci. 2008, 25, 1091-1098.

106. Vertova, A.; Aricci, G.; Rondinini, S.; Miglio, R.; Carnelli, L.; D’Olimpio, P. Electrodialytic recovery of light carboxylic acids from industrial aqueous wastes. J. Appl. Electrochem. 2009, 39, 2051-2059.

107. Kim, I.; Yamashita, N.; Tanaka, H. Photodegradation of pharmaceuticals and personal care products during UV and UV/H2O2 treatments. Chemosphere. 2009, 77, 518-525.

108. Bello, A.R.; de Angelis, D.D.; Domingos, R.N. Microbiological and physicochemical treatments applied to metallurgic industry aiming water use. Braz. Arch. Biol. Tech. 2008, 51, 391-397.

109. Winward, G.P.; Avery, L.M.; Stephenson, T.; Jefferson, B. Chlorine disinfection of grey water for reuse: Effect of organics and particles. Water Res. 2008, 42, 483-491.

(C) 2011 by the authors; licensee MDPI, Basel, Switzerland. This article is an open access article distributed under the terms and conditions of the Creative Commons Attribution license (http://creativecommons.org/licenses/by/3.0/). 